\title{
THE EFFECT OF EXPANDED GLASS AND POLYSTYRENE WASTE ON THE PROPERTIES OF LIGHTWEIGHT AGGREGATE CONCRETE
}

\author{
Jurga ŠEPUTYTE்-JUCIKE், Marijonas SINICA \\ Vilnius Gediminas Technical University, Scientific Institute of Thermal Insulation, \\ Linkmenu g. 28, LT-08217, Vilnius, Lithuania
}

Received 02 February 2016; accepted 03 March 2016

\begin{abstract}
The main objective of this study is to create a lightweight aggregate concrete (LWAC) with a low thermal conductivity coefficient using expanded glass (EG) aggregate, produced from waste glass or crushed expanded polystyrene waste, obtained by crushing waste packing tare of household appliances. Research related to the effects of the amount of Portland cement (PC) as well as EG aggregates and crushed expanded polystyrene waste on physical (density, thermal conductivity coefficient, water absorption and capillary coefficient) and mechanical (compressive strength) properties of LWAC samples are provided.

Insulating LWAC based on a small amount of PC and lightweight EG aggregates and crushed expanded polystyrene waste, with especially low thermal conductivity coefficient values (from 0.070 to $0.098 \mathrm{~W} /$ $(\mathrm{m} \cdot \mathrm{K})$ ) has been developed. A strong relationship between thermal conductivity coefficient and density of LWAC samples was obtained. The density of LWAC samples depending on the amount of PC ranged between 225 and $335 \mathrm{~kg} / \mathrm{m}^{3}$. A partial replacement of EG aggregate by crushed expanded polystyrene waste, results in relative density decrease of LWAC samples. In LWAC samples the increased amount of PC results in increased compressive strength.
\end{abstract}

Keywords: lightweight aggregate concrete, expanded glass, crushed expanded polystyrene waste, thermal conductivity coefficient, compressive strength, water adsorption, capillary coefficient.

\section{Introduction}

Lightweight aggregate concrete (LWAC) made from expanded glass (EG) aggregate is one of the latest types of concrete. The authors (Limbachiya et al. 2012) have stated that EG has been used in construction applications as lightweight non- and semi-structural material. Because of the low density of EG aggregates, the compressive strength of this material is relatively low (Macedo 2011; Bumanis et al. 2013). The use of EG aggregates in concrete production as partial replacement to natural aggregates has caused a decrease in compressive strength compared to control mix. As described before (Khatib et al. 2012), as the content of EG aggregates increases in the composition, the density value drops from $2328 \mathrm{~kg} / \mathrm{m}^{3}$ for the control mix to $1401 \mathrm{~kg} / \mathrm{m}^{3}$ for the concrete with $100 \%$ of EG aggregates and compressive strength value drops from 30.7 to $15.0 \mathrm{MPa}$. The studies indicate (Bumanis et al. 2013) that with the increase of EG aggregates in the content from 300 to $400 \mathrm{~kg} / \mathrm{m}^{3}$, the LWAC density decreased from 685 to $561 \mathrm{~kg} / \mathrm{m}^{3}$, thermal conductivity coefficient - from 0.163 to $0.140 \mathrm{~W} /(\mathrm{m} \cdot \mathrm{K})$, compressive strength - from 5.8 to $4.1 \mathrm{MPa}$. The density of LWAC depends on the density and the amounts of the lightweight materials used. It is possible to produce LWAC using lightweight aggregates or air entraining agents with a density as low as $70 \%$ less than normal weight concrete (Mehta, Monterio 1993; Neville 2011; Chi et al. 2013). The weakest component of LWAC is not the cement matrix or the interfacial transition zone 
but the aggregates. So the mechanical performance of LWAC is not only controlled by the cement matrix quality but also by the aggregate volume in concrete and the aggregate properties (Ke et al. 2009). For aggregates with density lower than $1000 \mathrm{~kg} / \mathrm{m}^{3}$, the elastic modulus and the compressive strength of LWAC are strongly affected by the volume fraction of aggregate. By incorporating such material in cement matrix of LWAC compression strength could be limited due to the EG aggregates compressive strength. Lightweight aggregate outer shell thickness, macro-porosity and broken grains percentage all affect the aggregate strength (Ravindrarajah 1999).

Expanded polystyrene (EPS) is also a potential aggregate in LWAC. EPS and its waste are used for various purposes (Bajdur et al. 2002; Laukaitis et al. 2005). The authors of (Khan 2002) indicate that by replacing $10 \%, 20 \%, 30 \%$ of the coarse aggregate by solid volume with EPS aggregate, the density of concrete reduces from 2455 to $2330 \mathrm{~kg} / \mathrm{m}^{3}, 2210$ and $2080 \mathrm{~kg} / \mathrm{m}^{3}$, respectively. It was shown that such EPS aggregate concrete is more durable when it is subjected to sulphate attack or freeze-thaw cycles. The studies (Laukaitis et al. 2005) have determined that crushed expanded polystyrene waste as well as EPS can be used as the aggregate for an insulating LWAC. The density of such LWAC was $150-170 \mathrm{~kg} / \mathrm{m}^{3}$, thermal conductivity coefficient $0.060-0.064 \mathrm{~W} /(\mathrm{m} \cdot \mathrm{K})$, compressive strength 0.25-0.28 MPa. An insulating LWAC with crushed expanded polystyrene waste was also tested in a work (Sinica et al. 2008). The researchers found that the insulating LWAC obtained with the density ranging between 150 and $350 \mathrm{~kg} / \mathrm{m}^{3}$ depending on crushed expanded polystyrene waste content, had the compressive strength of 0.09-0.42 $\mathrm{MPa}$ and bending strength of $0.09-0.39 \mathrm{MPa}$. The thermal conductivity coefficient of insulating LWAC varied from 0.048 to $0.095 \mathrm{~W} /(\mathrm{m} \cdot \mathrm{K})$ in direct proportion to its density.
As it is seen from the literature analysis the application and research of EG and crushed expanded polystyrene waste in LWAC is not sufficient. However they have great potential of use, taking into account the amount of mentioned waste and environmentallyfriendly nature. The density and thermal conductivity coefficient of LWAC is high in the literature presented above. In order to fully use the potential of aggregates and receive a lower density value, LWAC must be developed using the materials of low thermal conductivity coefficient to fully fill the cavities in its structure, e.g., crushed expanded polystyrene waste. However, there was no enough information about the effects of separate EG or EG and crushed expanded polystyrene waste on the compressive strength, thermal conductivity coefficient, density and etc. of these LWAC in the technical literature.

The main objective of this study is to create insulating LWAC with low thermal conductivity coefficient using EG aggregate, produced from waste glass or crushed expanded polystyrene waste, obtained by crushing waste packing tare of household appliances. Research related to the effects of the amount of PC as well as EG and crushed expanded polystyrene waste on physical (density, thermal conductivity coefficient and water absorption) and mechanical (compressive strength) properties of LWAC samples are provided.

\section{Materials and test methods of testing}

\subsection{Materials and their preparation}

In this study as aggregates EG granules with varying fraction size of $0-2 \mathrm{~mm}, 4-8 \mathrm{~mm}, 8-16 \mathrm{~mm}$ and crushed expanded polystyrene waste fraction of $0-2$ were used. Physical and mechanical properties of aggregates are presented in Table 1. Ordinary Portland cement CEM I 42.5 R, compliant with requirements of the standard LST EN 197-1 and produced by SC "Akmenès

Table 1. Physical and mechanical properties of different aggregates

\begin{tabular}{|l|c|c|c|c|}
\hline \multirow{2}{*}{\multicolumn{2}{|c|}{ Parameter (measurement units) }} & \multicolumn{3}{c|}{ Fraction, $\mathrm{mm}$} \\
\cline { 2 - 5 } & $0 \div 2$ & $4 \div 8$ & $8 \div 16$ & $0 \div 2$ \\
\cline { 2 - 5 } & $\mathrm{EG}$ & & & Crushed expanded polystyrene waste \\
\hline Bulk density $\left(\mathrm{kg} / \mathrm{m}^{3}\right)$ & 290 & 140 & 120 & 15.0 \\
\hline Thermal conductivity at $10^{\circ} \mathrm{C}(\mathrm{W} /(\mathrm{m} \cdot \mathrm{K}))$ & 0.077 & 0.059 & 0.052 & 0.042 \\
\hline Resistance to crushing $(\mathrm{MPa})$ & 1.2 & 1.1 & 1.0 & - \\
\hline The mass loss after 20 freezing and thawing cycles $(\%)$ & 1.3 & 1.9 & 2.4 & - \\
\hline Water absorption by immersion $(\%)$ & 10.0 & 9.5 & 8.0 & - \\
\hline
\end{tabular}


cementas" was used. The specific surface of the PC $4200 \mathrm{~cm}^{2} / \mathrm{g}$, bulk density $-1.15 \mathrm{~g} / \mathrm{cm}^{3}$, the start of setting - $140 \mathrm{~min}$, the end of setting - $190 \mathrm{~min}$, alkali content - maximum $0.8 \%$. Mineral composition in \%: $\mathrm{C}_{3} \mathrm{~S}-56.64, \mathrm{C}_{2} \mathrm{~S}-16.72, \mathrm{C}_{3} \mathrm{~A}-8.96$, and $\mathrm{C}_{4} \mathrm{AF}-10.59$.

Superplasticizer (SP) "Castament FS-40" a free flowing, spray dried powder of a polymerisation product based on polycarboxylate ester ( $\mathrm{pH}-6.5$ to $8.5 \%)$ was used.

As a pozzolanic additive - metakaolin-based waste (MW) was used. It is a technogenic waste, generated in the JSC "Stikloporas" during the EG manufacturing process. The specific surface of MW -8650 $\mathrm{cm}^{2} / \mathrm{g}$, density $-0.48 \mathrm{~g} / \mathrm{cm}^{3}$.

Air entraining admixture (AEA) "Ufapore TCO" (white powder, $\mathrm{pH} \sim 8$ of $5 \%$ water solution, the active substance content of $94 \%$ ) was used.

Different amount of mentioned materials were used for preparation forming mixtures. The composite compositions were selected based on two things, first of all was to get the lowest thermal conductivity coefficient, the second to keep a minimum strength. Selected aggregate ratio was 3:1:1 (large fraction of EG: medium fraction of EG: small fraction of EG). During the work the small fraction of EG was replaced by the EPS waste. The compositions of forming mixtures of insulating LWAC are provided in Table 2. All forming mixtures were prepared in a laboratory mixer with vertical rotation axis by forced mixing with speed 125 $\mathrm{rpm}$. The components were mixed until a homogenous forming mixture was obtained. For determination of the properties of hardened LWAC samples the moulds were kept in hermetic plastic bags for two days, then the samples were demoulded and kept for 7 and 28 days $\left(50 \% \mathrm{RH}\right.$ at $20 \pm 5{ }^{\circ} \mathrm{C}$ ) in a laboratory conditions.

\subsection{Density}

The density tests were performed according to LST EN 1602. The specimens of the size $100 \times 100 \times 100 \mathrm{~mm}$ were cut out of the boards. Before testing, the specimens were stored for 24 hours at the temperature of $23 \pm 2^{\circ} \mathrm{C}$ and relative humidity of $50 \pm 5 \%$.

Density $\rho$ was determined by the formula:

$$
\rho=\frac{m}{V}, \mathrm{~kg} / \mathrm{m}^{3},
$$

where: $m$ is the mass of the specimen, $\mathrm{kg}$; $V$ - the specimens volume, $\mathrm{m}^{3}$.

\subsection{Structure}

In order to analyse macro ( 20 times enlargement) and micro (100 times enlargement) structure of composites, specimens of $40 \times 40 \times 40 \mathrm{~mm}$ were prepared. The samples were inspected in a Zeiss EVO-50 EP Scanning Electron Microscope (SEM).

Analysis was performed using the variable pressure mode at an accelerating voltage of $20 \mathrm{keV}$ and working distance of $10 \mathrm{~mm}$ to $15 \mathrm{~mm}$.

\subsection{Compression}

The compression tests were performed according to EN 826. Square test specimens with the side of $100 \mathrm{~mm}$ were tested. The loading rate was $\left(0.1 \mathrm{~d}_{\mathrm{s}} \pm 25 \%\right) \mathrm{mm} /$ min (where $d_{s}$ is the thickness of the specimen, $\mathrm{mm}$ ).

Table 2. Compositions of forming mixtures of LWAC specimens

\begin{tabular}{|l|c|c|c|c|c|c|}
\hline \multirow{2}{*}{ Used materials (measurement units) } & \multicolumn{5}{|c|}{ Composition codes } \\
\cline { 2 - 7 } & 1 & 2 & 3 & 4 & 5 & 6 \\
\hline PC $\left(\mathrm{kg} / \mathrm{m}^{3}\right)$ & 70 & 100 & 130 & 70 & 100 & 130 \\
\hline $\mathrm{MW}\left(\mathrm{kg} / \mathrm{m}^{3}\right)$ & 7 & 10 & 13 & 7 & 10 & 13 \\
\hline SP $\left(\mathrm{kg} / \mathrm{m}^{3}\right)$ & 0.35 & 0.50 & 0.65 & 0.35 & 0.50 & 0.65 \\
\hline AEA $\left(\mathrm{kg} / \mathrm{m}^{3}\right)$ & 0.0175 & 0.0250 & 0.0325 & 0.0175 & 0.0250 & 0.0325 \\
\hline EG $8-16 \mathrm{~mm}\left(\mathrm{~kg} / \mathrm{m}^{3}\right)$ & 72 & 72 & 72 & 72 & 72 & 72 \\
\hline EG $4-8 \mathrm{~mm}\left(\mathrm{~kg} / \mathrm{m}^{3}\right)$ & 28 & 28 & 28 & 28 & 28 & 28 \\
\hline EG 0-2 $\mathrm{mm}\left(\mathrm{kg} / \mathrm{m}^{3}\right)$ & 58 & 58 & 58 & - & - & - \\
\hline $\begin{array}{l}\text { Crushed expanded } \\
\text { polystyrene waste } 0-2 \mathrm{~mm}\left(\mathrm{~kg} / \mathrm{m}^{3}\right)\end{array}$ & - & - & - & 5 & 5 & 5 \\
\hline Water $\left(\mathrm{kg} / \mathrm{m}^{3}\right)$ & 14 & 28 & 40 & 46 & 53 & 68 \\
\hline Water $/$ PC ratio & 0.20 & 0.28 & 0.31 & 0.66 & 0.53 & 0.52 \\
\hline Fresh unit weight $\left(\mathrm{kg} / \mathrm{m}^{3}\right)$ & 249.4 & 296.5 & 341.7 & 228.4 & 268.5 & 316.7 \\
\hline
\end{tabular}


The tests were conducted by using a computerised testing machine H10KS (Hounsfield, England). The uncertainty of force measurement ranged from 1 to $11 \mathrm{~N}$. The accuracy of movement of the cross head was $0.01 \mathrm{~mm}$. Such accuracy was sufficient for used relatively large test specimens. Basic software package QMAT Professional ver. 3.83 was used in testing. The tests were conducted at the ambient temperature of $23 \pm 2^{\circ} \mathrm{C}$ and relative humidity of $50 \pm 5 \%$.

\subsection{Thermal conductivity}

The investigations included loose fill EG granules with varying fraction size from 0 to $16 \mathrm{~mm}$, crushed expanded polystyrene waste of $0-2 \mathrm{~mm}$ and 6 types of composite. The nominal thickness of loose fill materials and composites was $100 \mathrm{~mm}$.

The measurement of all specimens thermal conductivity at mean temperature of $10^{\circ} \mathrm{C}$ was carried out on samples dimensioned $500 \times 500 \times 100 \mathrm{~mm}$ according to requirements of EN ISO 8302 and LST EN 12664 by quarded hot plate aparatus $\lambda$-Meter EP-500 (Germany).

The direction of heat flow was upward, the temperature difference between cold and hot plates made $15^{\circ} \mathrm{C}$. Calibration of device was carried out on reference measures of thermal conductivity meant for expanded polystyrene (EPS). Samples were preliminary brought to balanced hygroscopic moisture at temperature of $23 \pm 2{ }^{\circ} \mathrm{C}$ and relative humidity of $50 \pm 5 \%$.

\subsection{Long-term water absorption}

Water absorption tests were performed according to LST EN 12087. Water absorption of composites was determined in percent of volume for the immersion during 24 hours.

The specimens of the size $100 \times 100 \times 100 \mathrm{~mm}$, cut out of the boards of 6 types of composite, were prepared. A certain number of specimens were placed in an empty water tank and slightly pressed by a plate for total immersion. The water was poured until the tap face of the specimen was $50 \pm 2 \mathrm{~mm}$ below the water level.

The total number of the test specimens was 36 . Before testing, the specimens were stored for 24 hours at the temperature of $23 \pm 2^{\circ} \mathrm{C}$ and relative humidity of $50 \pm 5 \%$.

According to LST EN 12087, water absorption was determined using a method $2 \mathrm{~A}$ based on drain- age. A test specimen was taken out of the water tank and placed on a mesh cage made of stainless steel and forming chute with a slope of $45^{\circ}$. After $10 \pm 0,5 \mathrm{~min}$ of drainage, the specimens were weighed.

Water absorption $W_{\tau(2 A)}$ was determined by the formula:

$$
W_{\tau(2 A)}=\frac{m_{\tau}-m_{0}}{V} \cdot \frac{100}{\rho_{w}}, \%
$$

where: $m_{\tau}$ - the specimen mass after immersion over the period of time $\tau, \mathrm{kg} ; m_{0}$ - the initial mass of the specimen, $\mathrm{kg} ; \mathrm{V}$ - the initial specimens volume, $\mathrm{m}^{3}$; $\rho_{w}$ - water density equal to $1000 \mathrm{~kg} / \mathrm{m}^{3}$.

\subsection{Capillary coefficient}

Coefficient of water absorption due to capillary action of composite was determined according to EN 772-11. The specimens of the size $100 \times 100 \times 100 \mathrm{~mm}$ were cut out of the boards. Before testing, the specimens were stored for 24 hours at the temperature of $23 \pm 2^{\circ} \mathrm{C}$ and relative humidity of $50 \pm 5 \%$. The specimens were immersed in water to a depth of $5 \pm 1 \mathrm{~mm}$ for the indicated duration of the test. After the immersion time specimens were removed, their surface water was wiped off and all specimens weighed.

The coefficient of water absorption, $C_{w, s}$ of the material due to capillary action was calculated using the following formula:

$$
C_{w, s}=\frac{m_{s o, s}-m_{d r y, s}}{A_{s} \cdot t_{s o}} \cdot 10^{6}, \mathrm{~g} /\left(\mathrm{m}^{2} \cdot \mathrm{s}\right),
$$

where: $A_{s}$ - the cross area of the face of the specimen immersed in water, $\mathrm{mm}^{2} ; m_{s o, s}$ the mass of the specimen in grams after soaking for the time $t ; m_{d r y, s}$ - the mass of the specimen after drying, $g ; t_{s o}-$ the time of soaking, $s$.

Coefficient of water absorption due to capillary action of composite was determined after 90 minutes.

\section{Research Results}

\subsection{Structure}

View of macro and micro structures of lightweight aggregate concrete are presented in Figure 1. In Figure 1a test specimen with EG aggregates is presented. Air holes between EG granules are observed. The size of such holes varies from $1 \mathrm{~mm}$ to $3 \mathrm{~mm}$. When aggregates are mixed air holes are thoroughly filled by crushed expanded polystyrene waste (Fig. 1b). As it is stated in (Sinica et al. 2008), in large holes intensive thermal conductivity is observed. 

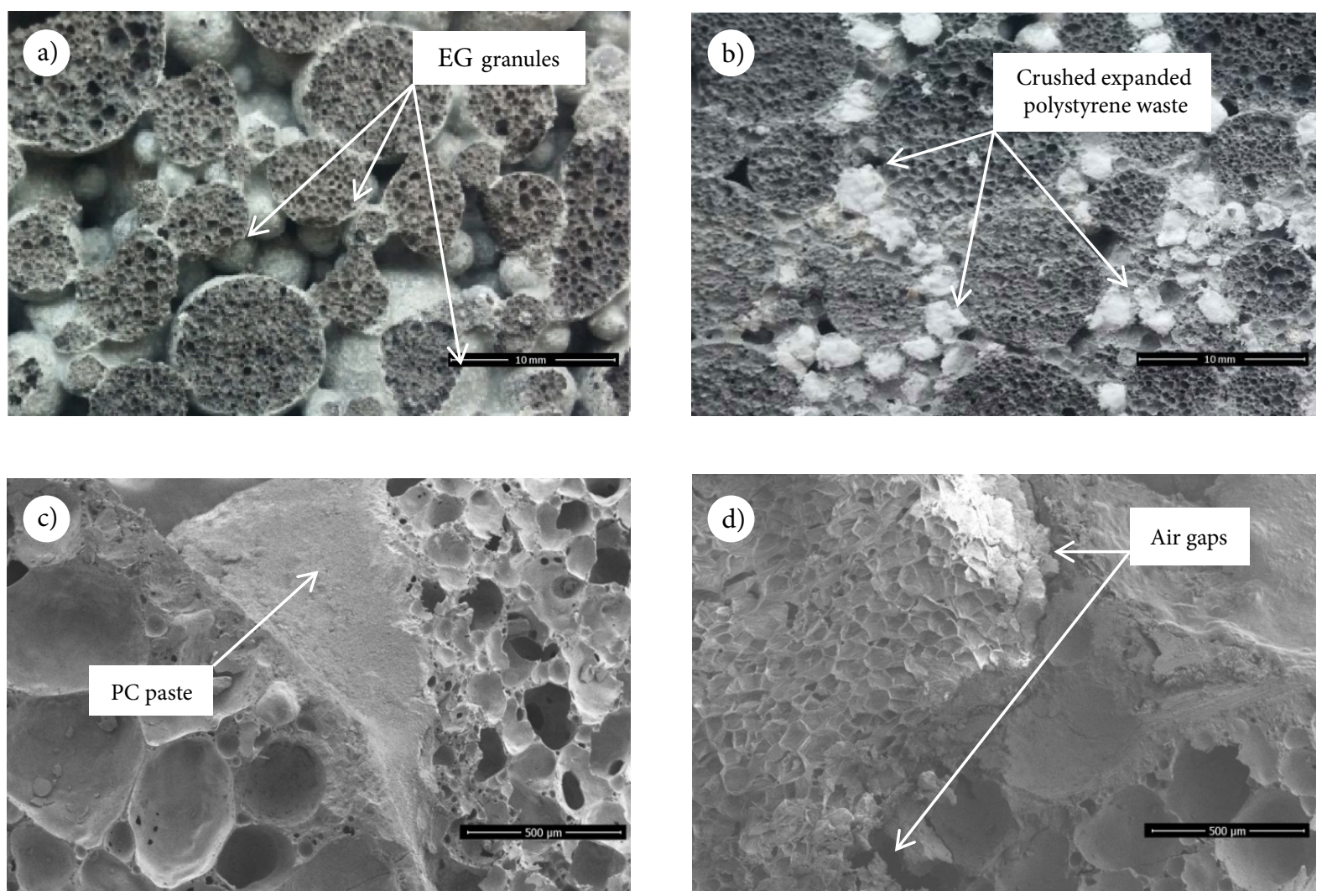

Fig. 1. View of lightweight aggregate composite: a - with EG aggregate; b - with mixed aggregate; c - contact zone between EG granules; $d$ - contact zone between EG and crushed expanded polystyrene waste particle

Contact zones between aggregates and binding material are presented in Figure 1c and Figure 1d. In Figure 1c different sized EG granules are connected by binding material - Portland cement paste. Well contact zone between granules and binding material is observed. In Figure 1d contact zone between crushed expanded polystyrene waste and EG is presented. In separate zones between crushed expanded polystyrene particle and EG air holes are observed. It indicates poor adhesion between crushed expanded polystyrene waste and binding material.

\subsection{Density}

One of the main properties describing the LWAC samples is their density. Depending on the amount of PC, the density of LWAC samples only with EG aggregate ranges between 247 and $335 \mathrm{~kg} / \mathrm{m}^{3}$ (Fig. 2, compositions 1, 2 and 3). As the amount of PC increases, W/C increases as well. When the amount of PC increased, the density of LWAC samples increases accordingly by 19 and $36 \%$.

Density of LWAC samples, where a part of EG aggregate is replaced by crushed expanded polysty- rene waste, ranges between 225 and $309 \mathrm{~kg} / \mathrm{m}^{3}$ (Fig. 2, compositions 4, 5 and 6). In these LWAC samples, the increase of PC amount from 70 to 100 or $130 \mathrm{~kg} / \mathrm{m}^{3}$ resulted in an increase of the density by 24 and $27 \%$.

A partial replacement of EG aggregate by crushed expanded polystyrene waste, results in relative density decrease by 9,10 and $8 \%$ respectively, comparing with LWAC samples only with EG aggregates which density was assimilated to $100 \%$ (Fig. 3).

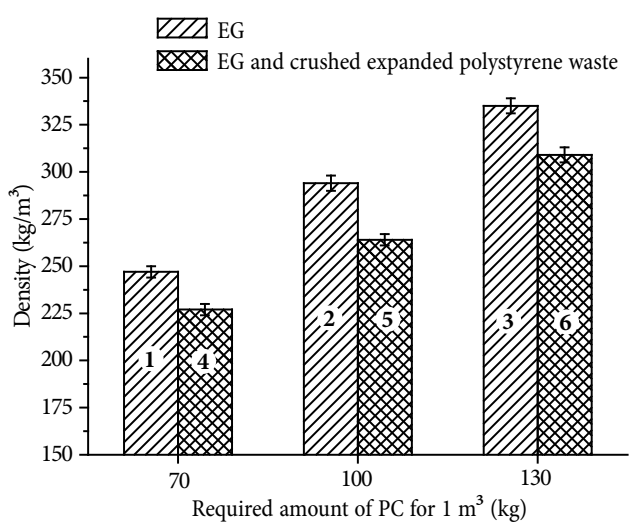

Fig. 2. Influence of the amount of PC on density of LWAC samples of $1 \div 6$ compositions 


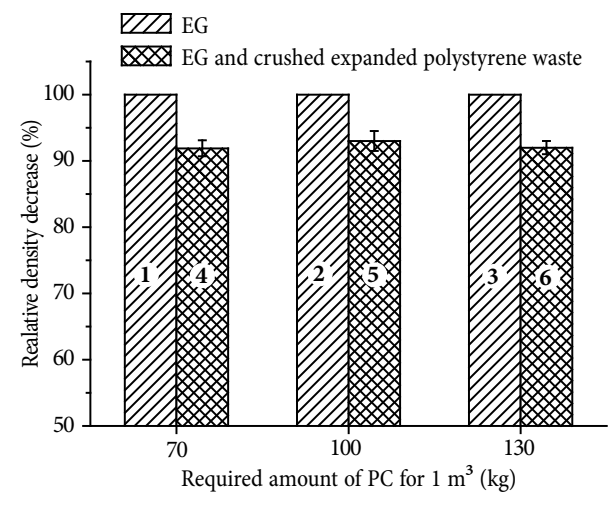

Fig. 3. Influence of the amount of PC on relative density decrease of LWAC samples of $1 \div 6$ compositions

\subsection{Compressive strength}

Many studies show that LWAC samples do not have high strength characteristics (Laukaitis et al. 2005; Sinica et al. 2008; Kligys 2009). LWAC can be classified into different groups based on their density and compressive strength (Kligys 2009). There are generally three types of LWAC: (1) lightweight aggregate concrete (voids are mainly in aggregates); (2) cellular concrete and foam concrete (voids are in cement paste) and (3) no fines concrete (sand is eliminated) and voids are between coarse aggregate particles (Wang et al. 2013). On a microstructural scale, LWAC can be considered as a three-phase composite model consisting of mortar matrix (or PC paste), aggregate, and interfacial zone between PC paste and aggregate (Lanzo, Garcia-Ruiz 2008). As the normal aggregate is replaced by the porous one (EG or EPS), compressive strength of LWAC is reduced due to lower strength of mentioned aggregates (Lo et al. 2007; Yu et al. 2013). Due to porous aggregates and matrix, and the absence of fine sand in the fraction of aggregates, LWAC tested in this work has all three above mentioned indications.

The developed LWAC of different composition has different compressive strength, which depends on the aggregate type, amount of PC and W/C ratio. The air entrainment also has an influence on the low compressive strength of the LWAC samples.

In LWAC samples only with EG aggregate, increased amount of PC from 70 to 100 or $130 \mathrm{~kg} / \mathrm{m}^{3}$, results in increased compressive strength after 7 days of hardening accordingly by 1.96 and 2.25 times and ranged between 0.32 and $0.72 \mathrm{MPa}$ (Fig. 4, compositions 1, 2 and 3). The compressive strength of LWAC samples, where a part of EG aggregate is replaced by crushed expanded polystyrene waste, increased twice with the increase of PC amount and ranged between 0.31 and $0.62 \mathrm{MPa}$ (Fig. 4, compositions 4, 5 and 6).

Research results of compressive strength after 28 days of hardening showed that in LWAC samples only with EG aggregate (Fig. 5, compositions 1, 2 and 3), the change is similar and ranges between 0.38 and $0.85 \mathrm{MPa}$ (increased by $22.6-18 \%$ in comparison to compressive strengths after 7 days of hardening). In LWAC samples, where a part of EG aggregate was replaced by crushed expanded polystyrene waste (Fig. 5, compositions 4, 5 and 6), the compressive strength after 28 days of hardening ranged between 0.35 and $0.73 \mathrm{MPa}$ (increased by $13-17.7 \%$ in comparison to compressive strength after 7 days of hardening). It can be explained by a poor adhesion of PC paste and crushed expanded polystyrene waste (Laukaitis et al. 2005; Saikia, Brito 2012). It should be noted that W/C ratio in these LWAC samples is higher, and also influences the loss of compressive strength as pointed in works (Wong, Buenfeld 2009; Lo et al. 2007). The values of compressive strength after 28 days of hardening of LWAC samples, where a part of EG aggregate

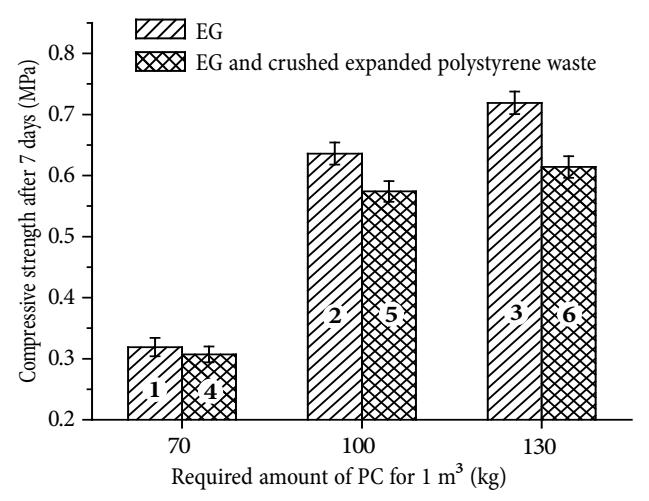

Fig. 4. Influence of the amount of PC on compressive strength after 7 days of LWAC samples of $1 \div 6$ compositions

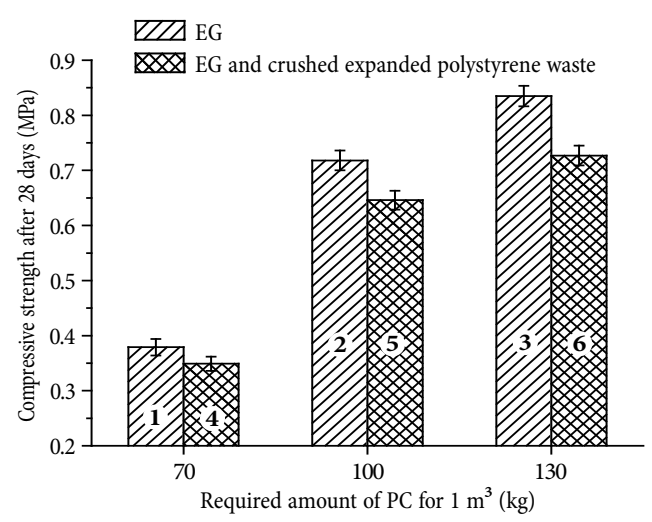

Fig. 5. Influence of the amount of PC on compressive strength after 28 days of LWAC samples of $1 \div 6$ compositions 
is replaced by crushed expanded polystyrene waste, is by 8,10 and $14 \%$ lower comparing to the values of analogous LWAC samples only with EG aggregate. Research results (Laukaitis et al. 2005) of LWAC samples with EPS aggregate of similar density $\left(150-300 \mathrm{~kg} / \mathrm{m}^{3}\right)$ have showed that their compressive strength ranges between 0.25-0.55 MPa. For LWAC, the compressive strength is strongly connected with their density (Yu et al. 2013), and it decreases (increases) with the decrease (increase) of a density.

\subsection{Thermal conductivity coefficient}

As a moisture content affects the thermal conductivity coefficient (Khan 2002), all the LWAC samples were tested in a dry condition. It is known that the higher ratio of voids the sample has, the lower is its density and thermal conductivity coefficient (Bouguerra et al. 1998). Research results of the physical properties of LWAC samples with different aggregates and amount of PC show that the thermal conductivity coefficient linearly depends on their density (Fig. 6). In LWAC samples only with EG aggregate, the thermal conductivity coefficient ranges between 0.073 and $0.097 \mathrm{~W} /$ $(\mathrm{m} \cdot \mathrm{K})$.

In LWAC samples, where a part of EG aggregate is replaced by crushed expanded polystyrene waste, the thermal conductivity coefficient is reduced due to the lower density and porous structure of the crushed expanded polystyrene waste aggregate. Porosity is one of the factors affecting the thermal conductivity coefficient of LWAC. Low thermal conductivity of air entrapped in closed pores results in reduced thermal conductivity coefficient of LWAC (Demirboga, Gul 2003). The researchers (Laukaitis et al. 2005) have studied the LWAC with EPS aggregate and determined that the lowest value of thermal conductivity coefficient $(0.060 \mathrm{~W} /(\mathrm{m} \cdot \mathrm{K}))$, was obtained for a LWAC with the ratio of PC to fine EPS being 1:3 (Laukaitis et al. 2005). A partial replacement of EG aggregate by crushed expanded polystyrene waste increases the amount of closed pores in LWAC samples because of different pore nature of mentioned aggregates leading to reduced thermal conductivity coefficient. Thermal conductivity coefficient of these LWAC samples ranges between 0.071 and $0.087 \mathrm{~W} /(\mathrm{m} \cdot \mathrm{K})$. Research results confirm that EPS and crushed expanded polystyrene waste can significantly improve the thermal conductivity coefficient of LWAC samples of various compositions in a wide range.

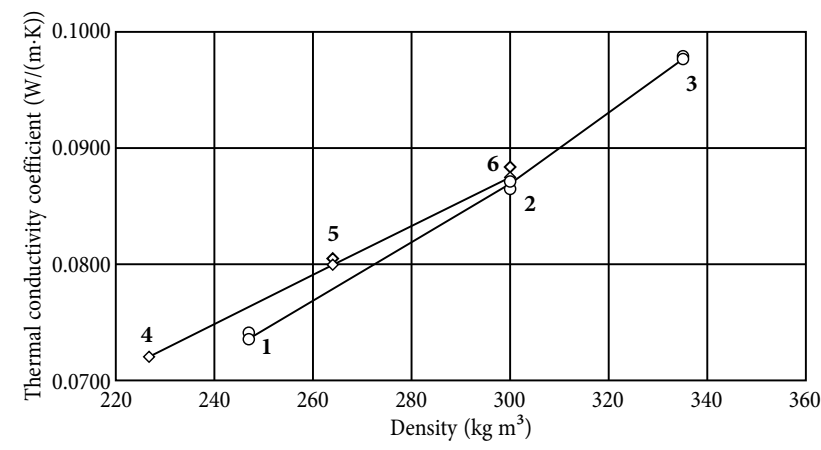

Fig. 6. Influence of the amount of PC on density and thermal conductivity coefficient of LWAC samples of $1 \div 6$

There is a clear tendency also noted by other authors (Ünal et al. 2007; Ashworth, T., Ashworth, E. 1991; FIP State of Art Report 1978) that the increase of amount of PC increases thermal conductivity coefficient of LWAC samples. As it is seen in Figure 6 and Equations (4) and (5), there is a strong relationship $\left(R^{2}-0.997\right.$ and $\left.R^{2}-0.995\right)$ between the density and thermal conductivity coefficient of LWAC samples. Average square deviations $\left(S_{r}\right)$ are 0.000369 and 0.000818 $\mathrm{W} /(\mathrm{m} \cdot \mathrm{K})$, respectively.

For LWAC samples (compositions 1, 2 and 3), the Equations:

$$
\lambda_{10}=0.00228+0.00001 \cdot \rho,
$$

with $R^{2}-0.997$ and $S_{r}-0.000369$,

where: $\rho$ - the density of the specimen, $\mathrm{kg} / \mathrm{m}^{3} ; \lambda_{10}-$ the thermal conductivity coefficient of the specimen, $\mathrm{W} /(\mathrm{m} \cdot \mathrm{K}) ; R^{2}$ - the correlation coefficient; -- standard deviation.

For LWAC samples (compositions 4, 5 and 6), the equation is:

$$
\lambda_{10}=0.00641+0.00027 \cdot \rho,
$$

with $R^{2}-0.995$ and $S_{r}-0.000818$ č

where: $\rho$ - the density of the specimen, $\mathrm{kg} / \mathrm{m}^{3} ; \lambda_{10}-$ the thermal conductivity coefficient of the specimen, $\mathrm{W} /(\mathrm{m} \cdot \mathrm{K}) ; R^{2}$ - the correlation coefficient; $S_{r}-$ standard deviation.

\subsection{Water absorption}

Research results of water absorption of LWAC samples after 24 hours are presented in Figure 7. It shows that regardless of the aggregate used, as the amount of PC is increased, higher density and lower water absorption of LWAC samples is obtained. It also confirmed in works (Lo et al. 2007). The water absorption of LWAC 


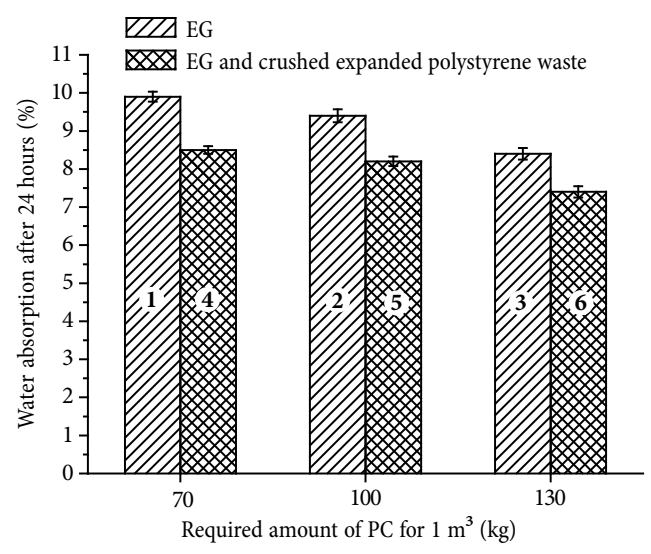

Fig. 7. Influence of the amount of PC on water absorption of LWAC samples of $1 \div 6$ compositions

samples only with EG aggregate decreased from 9.9 to $8.4 \%$ after the increase of amount of PC from 70 to $130 \mathrm{~kg} / \mathrm{m}^{3}$.

In the LWAC samples where a part of EG aggregate is replaced by crushed expanded polystyrene waste, increased amount of PC, results in decreased (from 8.5 to $7.4 \%$ ) water absorption, comparing with the LWAC samples with only EG aggregate. A partial replacement of EG aggregate by crushed expanded polystyrene waste increases the amount of closed pores in LWAC samples because of different pore nature of mentioned aggregate (crushed expanded polystyrene waste practically do not absorb water) leading to reduced water absorption.

Water absorption of LWAC samples of all 6 compositions is not high, because of low water absorption of EG aggregate. It is important with regard to the fact that high water absorption can affect the durability of the LWAC since most of the aggressive substances are transported with water (Lanzo, Garcia-Ruiz 2008). The obtained results of water absorption of LWAC samples mean that special coatings by commercially available water proofing materials, which may prevent the capillary absorption of water, will not be necessary (there will be no additional costs).

\subsection{Capillary coefficient}

Research results have showed that depending on the amount of PC, the capillary coefficient of LWAC samples only with EG aggregate after 90 minutes was practically the same $-0.4 \mathrm{~g} / \mathrm{m}^{2}$ s (Fig. 8 , compositions 1,2 and 3).

The capillary coefficient of LWAC samples, where a part of EG aggregate is replaced by crushed ex-

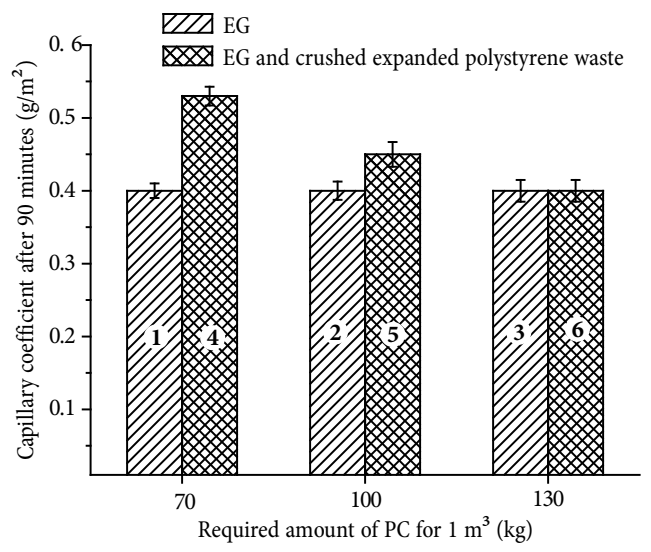

Fig. 8. Influence of the amount of PC on capillary coefficient of LWAC samples of $1 \div 6$ compositions

panded polystyrene waste, after 90 minutes was a little bit higher comparing with LWAC samples only with EG aggregates. Increased amount of PC, results in decreased capillary coefficient of LWAC samples and ranged between 0.53 and $0.40 \mathrm{~g} / \mathrm{m}^{2} \mathrm{~s}$ (Fig. 8, compositions 4, 5 and 6).

The amount of PC does not have a significant effect on a capillary coefficient of LWAC samples as PC adheres well to the porous surface of EG aggregate and coats it well (the capillary coefficient of EG aggregates is not high either).

Research results (Sinica et al. 2008) of LWAC samples with crushed expanded polystyrene waste of similar density show that if the density of LWAC samples ranges between 150 and $350 \mathrm{~kg} / \mathrm{m}^{3}$, the capillary coefficient ranges between 1.5 and $0.47 \mathrm{~g} / \mathrm{m}^{2} \mathrm{~s}$.

The data (UAB „Aeroc“ 2015) of LWAC products of similar density presented by manufacturers indicate that if the density is 425,375 and $300 \mathrm{~kg} / \mathrm{m}^{3}$, the capillary coefficient accordingly is $1.10,1.04$ and $0.986 \mathrm{~g} /$ $\mathrm{m}^{2} \mathrm{~s}$.

\section{Conclusions}

1. Insulating LWAC based on a small amount of PC and lightweight EG aggregate and crushed expanded polystyrene waste, with especially low thermal conductivity coefficient values (from 0.070 to 0.098 $\mathrm{W} /(\mathrm{m} \cdot \mathrm{K}))$ has been developed. A strong relationship between thermal conductivity coefficient and density of LWAC samples was obtained.

2. In LWAC samples increased amount of PC results in increased thermal conductivity coefficient. In LWAC samples only with EG aggregate, depending on the amount of PC, the thermal conductivity co- 
efficient ranges between 0.074 and $0.098 \mathrm{~W} /(\mathrm{m} \cdot \mathrm{K})$. In the LWAC samples where a part of EG aggregate is replaced by crushed expanded polystyrene waste, depending on the amount of PC, the thermal conductivity coefficient ranges from 0.070 to $0.086 \mathrm{~W} /$ $(\mathrm{m} \cdot \mathrm{K})$.

3. In LWAC samples increased amount of PC results in increased compressive strength. The values of compressive strength after 28 days of hardening of LWAC samples, where a part of EG aggregate is replaced by crushed expanded polystyrene waste, depending on the amount of PC, are by $8-14 \%$ lower comparing to the values of analogous LWAC samples only with EG aggregate.

4. Density of LWAC samples only with EG aggregate ranges between 247 and $335 \mathrm{~kg} / \mathrm{m}^{3}$. In the LWAC samples where a part of EG aggregate is replaced by crushed expanded polystyrene waste, density ranges between 225 and $309 \mathrm{~kg} / \mathrm{m}^{3}$. In LWAC samples a partial replacement of EG aggregate by crushed expanded polystyrene waste, depending on the amount of PC, reduces the density accordingly by 9-15\%.

5. The increase of amount of PC reduces water absorption, irrespective of the type of aggregate used in LWAC samples. In LWAC samples a partial replacement of EG aggregate by crushed expanded polystyrene waste decreases the water absorption due to lower density of samples.

6. In LWAC samples only with EG aggregate, the increase of amount of PC has no effect on the capillary coefficient. In LWAC samples a partial replacement of EG aggregate by crushed expanded polystyrene waste, slightly increases the capillary coefficient. The capillary coefficient of LWAC samples is less affected by the amount of PC than by the type of aggregate.

7. Due to low compressive strength, densities and thermal conductivity coefficients, concretes obtained in this work can be classified as thermal insulating LWAC. The wide range of low thermal conductivity coefficients and densities, combined with the ability to cast in any desired shape, enables to create LWAC as a very suitable material for using as flooding insulation in partitions of civil and industrial buildings. It shows that LWAC presented in this study are competitive.

\section{Acknowledgements}

The scientific investigations presented in this paper were financed by the Agency for Science, Innovation and Technology (International project EUREKA E! 8790-Enclosurewasteconcrete).

\section{References}

Ashworth, T.; Ashworth, E. 1991. Insulation materials: testing and applications, in R. S. Graves, D. C. Wysocki (Eds.). ASTM Special Technical Publication. Vol. 1116. ASTM, Philadelphia, PA.

Bajdur, W.; Pajaczkowska, J.; Makarucha, B.; Sulkowska, A.; Sulkowski, W. W. 2002. Effective polyelectrolytes synthesized from expanded polystyrene wastes, European Polymer Journal 38(2): 299-304.

http://dx.doi.org/10.1016/S0014-3057(01)00191-4

Bouguerra, A.; Ledhem, A.; Barquin, F. De.; Dheilly, R. M.; Queneudec, M. 1998. Effect of microstructure on the mechanical and thermal properties of lightweight concrete prepared from clay, cement, and wood aggregate, Cement and Concrete Research 28(8): 1179-1190. http://dx.doi.org/10.1016/S0008-8846(98)00075-1

Bumanis, G.; Bajare, D; Korjakins, A. 2013. Mechanical and thermal properties of lightweight concrete made from expanded glass, Journal of Sustainable Architecture and Civil Engineering 2(3): 26-32.

http://dx.doi.org/10.5755/j01.sace.2.3.2790

Demirboga, R.; Gul, R. 2003. The effects of expanded perlite aggregate, silica fume and fly ash on the thermal conductivity of lightweight concrete, Cement and Concrete Research 33(5): 723-727. http://dx.doi.org/10.1016/S0008-8846(02)01032-3

Chi, J. M.; Huang, R.; Yang, C. C.; Chang, J. J. 2003. Effects of aggregate properties on the strength and stiffness of lightweight concrete, Cement and Concrete Composites 25(2): 197-205. http://dx.doi.org/10.1016/S0958-9465(02)00020-3

EN ISO 8302:1991. Thermal insulation - Determination of steady-state thermal resistance and related properties - Guarded hot plate aparatus.

FIP State of Art Report. 1978. Principles of thermal insulation with respect to lightweight concrete, FIP/8/1, C and CA, Slought, England.

Ke, Y.; Beaucor, A. L.; Ortola, S.; Dumontet, H.; Cabrillac, R. 2009. Influence of volume fraction and characteristics of lightweight aggregates on the mechanical properties of concrete, Construction and Building Materials 23(8): 2821-2828. http://dx.doi.org/10.1016/j.conbuildmat.2009.02.038

Khan, M. I. 2002. Factors affecting the thermal properties of concrete and applicability of its prediction models, Building and Environment 37(6): 607-614. http://dx.doi.org/10.1016/S0360-1323(01)00061-0

Khatib, J. M.; Shariff, S.; Negim, E. M. 2012. Effect of incorporating foamed glass on the flexural behaviour of reinforced concrete beams, World Applied Sciences Journal 19(1): 4751. http://dx.doi.org/10.5829/idosi.wasj.2012.19.01.2763

Kligys, M. 2009. Production technology and properties of composite material made out of porous cement paste and crushed expanded polystyrene: $\mathrm{PhD}$ dissertation. Vilnius Gediminas Technical University, Lithuania. 
Lanzo, M.; Garcia-Ruiz, P. A. 2008. Lightweight cement mortars: advantages and inconveniences of expanded perlite and its influence on fresh and hardened state and durability, Construction and Building Materials 22(8): 1798-1806. http://dx.doi.org/10.1016/j.conbuildmat.2007.05.006

Laukaitis, A.; Žurauskas, R.; Kerienè, J. 2005. The effect of foam polystyrene granules on cement composite properties, $\mathrm{Ce}$ ment and Concrete Composites 27(1): 41-47.

http://dx.doi.org/10.1016/j.cemconcomp.2003.09.004

Limbachiya, M.; Meddah, M.; Fotiadou, S. 2012. Performance of granulated foam glass concrete, Construction and Building Materials 28(1): 759-768.

http://dx.doi.org/10.1016/j.conbuildmat.2011.10.052

Lo, T. Y.; Tang, W. C.; Cui, H. Z. 2007. The effects of aggregate properties on lightweight concrete, Building and Environment 42(8): 3025-3029. http://dx.doi.org/10.1016/j.buildenv.2005.06.031

LST EN 197-1:2011. Cementas. 1 dalis. Iprastiniu cementy sudetis, techniniai reikalavimai ir atitikties kriterijai $[\mathrm{Ce}-$ ment - part 1: composition, specifications, and conformity criteria for common cements]. Lithuanian Standard.

LST EN 826:2013. Statybiniai termoizoliaciniai gaminiai. Elgsenos gniuždant nustatymas [Thermal insulating products for building applications - Determination of compression behaviour]. Lithuanian Standard.

LST EN 12664:2002. Šiluminess statybiniu medžiagu ir gaminiu charakteristikos. Šilumines varžos nustatymas apsaugotos karštosios plokštès ir šilumos srauto matuoklio metodais. Vidutines ir mažos šilumines varžos sausi ir drégni gaminiai [Thermal performance of building materials and products Determination of thermal resistance by means of guarded hot plate and heat flow meter methods - Dry and moist products of medium and low thermal resistance]. Lithuanian Standard.

LST EN 12087:2013. Statybiniai termoizoliaciniai gaminiai. Ilgalaikes vandens sugerties panardinus jame nustatymas [Thermal insulating products for building applications - Determination of long term water absorption by immersion]. Lithuanian Standard.

LST EN 772-11:2011. Mūro gaminiu bandymo metodai. 11 dalis. Užpildu betono, autoklavinio akytojo betono, dirbtinio ir gamtinio akmens mūro gaminiu kapiliarinio vandens igerties ir keraminiu mūro gaminiu pradines vandens igerties spartos nustatymas [Methods of test for masonry units - Part 11: Determination of water absorption of aggregate concrete, autoclaved aerated concrete, manufactured stone and natural stone masonry units due to capillary action and the initial rate of water absorption of clay masonry units]. Lithuanian Standard.
Macedo, P. M. B. 2011. Strong, lower density composite concrete building material with foam glass aggregate, Patent 7695560, US. Available from Internet: http://www.google. com/patents/US7695560

Mehta, P. K.; Monterio, P. J. M. 1993. Concrete structure properties and materials. England Cliffs, NJ: Prentice Hall.

Neville, A. M. 2011. Properties of concrete. London: Pearson Education.

Ravindrarajah, R. S. 1999. Bearing strength of concrete containing polystyrene aggregate, Durability of building materials and components 8. Ottawa, Canada: Institute for Research in Construction, 505-514.

Saikia, N.; Brito, J. D. 2012. Use of plastic waste as aggregate in cement mortar and concrete preparation: A review, Construction and Building Materials 34: 385-401. http://dx.doi.org/10.1016/j.conbuildmat.2012.02.066

Sinica, M.; Laukaitis, A.; Sezemanas, G.; Kligys, M. 2008. Operational properties of a heat-insulation composite with expanded polystyrene crumbs, Mechanics Composite Materials 44(4): 415-424. http://dx.doi.org/10.1007\%2Fs11029-008-9033-x

UAB "Aeroc". 2015. Drégmès ir vandens igeriamumo reikšmé blokeliams [online], [15 January 2016]. Available from Internet: http://lt.lt.allconstructions.com/portal/categories/95/1/0/1/article/17655/dregmes-ir-vandens-igeriamumo-reiksme-blokeliams

Ünal, O.; Uygunoglu, T.; Yildiz, A. 2007. Investigation of properties of low-strength lightweight concrete for thermal insulation, Building and Environment 42(2): 584-590. http://dx.doi.org/10.1016/j.buildenv.2005.09.024

Wang, J. Y.; Chia, K. S.; Liew, J. Y. R.; Zhang, M. H. 2013. Flexural performance of fiber-reinforced ultra lightweight cement composites with low fiber content, Cement and Concrete Composites 43: 39-47.

http://dx.doi.org/10.1016/j.cemconcomp.2013.06.006

Wong, H. S.; Buenfeld, N. R. 2009. Determining the watercement ratio, cement content, water content and degree of hydration of hardened cement paste: Method development and validation on paste samples, Cement and Concrete Research 39(10): 957-965. http://dx.doi.org/10.1016/j.cemconres.2009.06.013

Yu, Q. L.; Spiesz, P.; Brouwers, H. J. H. 2013. Development of cement-based lightweight composites - Part 1: Mix design methodology and hardened properties, Cement and Concrete Composites 44: 17-29. http://dx.doi.org/10.1016/j.cemconcomp.2013.03.030

Jurga ŠEPUTYTĖ-JUCIKE். PhD student, Master of Science in Vilnius Gediminas Technical University in 2012 (Construction Technologies). Author and co-author of 8 scientific publications and 1 patent. Research interests: lightweight concretes and composites, technologic wastes, insulating materials, their properties, technology and application.

Marijonas SINICA, Prof, Dr, a graduate of Vilnius Institute of Civil Engineering in 1971 (Mechanics). Doctor's degree in 2001, habilitation procedure in 2009, professor in 2012. Author and co-author of 1 monograph, 72 scientific publications, 39 inventions and 8 patents. Research interests: enclosures, influence of dispersive and fibrous inserts on the structure and properties of composite materials, porous concrete, thermal, heat and sound insulating materials, technology and application of materials. 